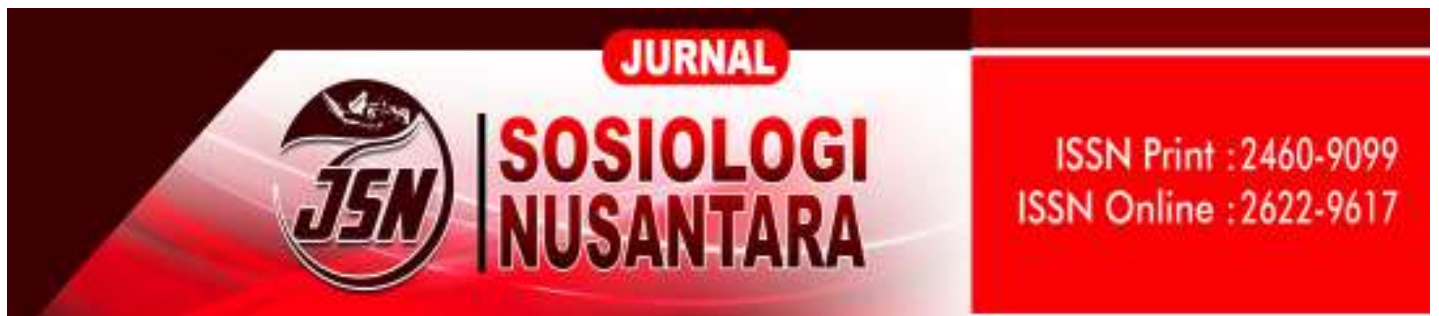

https://ejournal.unib.ac.id/index.php/jsn

DOI ://doi.org/10.33369/jsn.7.1.77-88

\title{
PERAN SUPERVISOR DALAM MENJAGA ETOS KERJA KARYAWAN PT ANEKA JASA TEKNIK GROUP GRESIK
}

\section{SUPERVISOR'S ROLE IN MAINTAINING EMPLOYEE'S WORK ETHIC OF PT ANEKA JASA TEKNIK GROUP GRESIK}

\author{
Sulismadi ${ }^{1}$, Tutik Sulistyowati ${ }^{2}$, Alung Vinedal ${ }^{3}$ \\ alungvinedal340@gmail.com , tutiksulistyowati@umm.ac.id , sulismadi@gmail.com \\ 1,2,3 Program Studi Sosiologi Fakultas Ilmu Sosial dan Ilmu Politik, \\ Universitas Muhammadiyah Malang
}

\begin{abstract}
Abstrak
Supervisor adalah sebuah peran dalam perusahaan untuk menyampaikan substansi tertentu dari perusahaan kepada karyawan atau sebaliknya, serta bertanggung jawab dalam pelaksanaan proses produksi. Secara struktural posisi supervisor adalah berada di bawah manajer dan di atas karyawan. Para supervisor bertanggung jawab dalam memecahkan masalah, mengambil keputusan dan tindakan dalam sebuah produk yang dihasilkan oleh para karyawan untuk perusahaan. Tujuan dari penulisan ini untuk mengetahui dan menganalisis permasalahan dengan cara melakukan evaluasi terhadap peran supervisor untuk menjaga etos kerja karyawan PT. Aneka Jasa Teknik Group Gresik. Melalui pendekatan kualitatif deskriptif, pengambilan data dilakukan dengan cara observasi, studi pustaka, dan wawancara. Permasalahan yang telah ditemukan yaitu ketidaksesuaian skill (keterampilan) karyawan dengan permintaan supervisor. Kualitas kerja karyawan dapat terganggu karena hal tersebut. Jika terdapat penurunan kinerja karyawan seperti demikian maka supervisor akan turun tangan secara langsung dengan melakukan komunikasi intensif dengan karyawan untuk memahami akar permasalahannya tanpa melibatkan atasan terlebih dahulu.
\end{abstract}

Kata Kunci : Etos Kerja, Karyawan, Supervisor

\section{Abstract}

Supervisor is a role in a company to convey their certains subtances to employees or vice versa, as well as responsible on implementation of production process. Structurally, supervisor is under manager and above employee. Supervisors are responsible on problem solving, making decision, and action of production process. 
78 I Sulismadi, Tutik Sulistyowati, Alung Vinedal

Peran Supervisor Dalam Menjaga Etos Kerja Karyawan PT Aneka Jasa Teknik Group Gresik

The purpose of this writing is to find and analyze the problem by evaluating the role of supervisors to maintain the work ethic of PT Aneka Jasa Teknik Group's employees. Through a descriptive qualitative approach, data retrieval is conducted by observation, book studies, and interviews. The problem that has been found is about the skill incompatibility of employees compared with the request of supervisors. The quality of employees' work may be impaired due to this. If there is such a decrease in employee's performance then the supervisor will intervene directly by conducting intensive communication with employees to understand the root cause without involving the management first.

Keywords : Employees, Supervisors, Work Ethic

\section{PENDAHULUAN}

Setiap perusahaan perlu memperhatikan beberapa faktor produksi sebagai upaya untuk meningkatkan intensitas perusahaan. Faktor tersebut antara lain faktor tenaga kerja, mesin, metode, pemasaran, dan material. Faktor tenaga kerja dapat membentuk manajemen sumber daya manusia dengan cara memperkuat dalam pengelolaan dan pengembangan potensi masyarakat. Menurut (Titisari \& Haryono, 2016) etos kerja yang baik dapat diwujudkan apabila karyawan terbiasa untuk hidup disiplin sehingga pekerjaan yang dilakukannya dapat diselelsaikan dengan tepat waktu dan tertata dengan baik.

Tenaga kerja merupakan suatu aset bagi perusahaan untuk melaksanakan perencanaan kegiatan perusahaan. Produktivitas tenaga kerja merupakan faktor terpenting bagi perusahaan untuk meningkatkan kapasitas produksi secara maksimal. Menurut (Husein Umar, 1998) dalam (Dadang \& Heriyanto, 2020) Manajemen Sumber Daya Manusia (MSDM) adalah serangkaian proses yang mencakup perencanaan, kompensasi, pemeliharaan, pemutusan hubungan kerja dan sebagainya guna tercapainya tujuan dari organisasi perusahaan. Pengembangan SDM merupakan suatu upaya untuk meningkatkan kualitas dan kemampuan SDM supaya dapat mensejahterakan masyarakat sebagai tujuan dari perusahaan. Manajemen SDM yang baik dapat mempermudah terwujudnya tujuan perusahaan itu sendiri. Manajemen SDM dijalankan oleh supervisor yang kemudian bertanggung jawab kepada manajer.

Supervisor adalah sebuah peran dalam perusahaan untuk menyampaikan substansi tertentu dari perusahaan kepada karyawan atau sebaliknya, serta 
bertanggung jawab dalam pelaksanaan proses produksi. Menurut struktural perusahaan, manajer membawahi supervisor yang kemudian di bawahnya adalah posisi karyawan, dengan kata lain supervisor adalah yang menjembatani antara manajemen dan karyawan (Dadang \& Heriyanto, 2020). Fungsi dari supervisor yaitu membantu para karyawan untuk mencapai target-target kerja yang ingin dicapai di perusahaan. Target tersebut diantara lain suasana kerja sehingga memberikan kenyamanan dan saling menghargai sesama karyawan dalam melakukan sebuah pekerjaan. Supervisor berfungsi sebagai pemimpin yang dapat membangkitkan semangat dari para anggota. Supervisor memberikan contoh membentuk suasana kerja sama yang baik dalam perusahaan sehingga para karyawan termotivasi untuk memaksimalkan kinerjanya.

Kegiatan yang dilakukan supervisor biasanya melibatkan diri secara langsung dengan karyawan. Tanggung jawab utama seorang supervisor adalah mengkoordinasikan sistem kerja secara kondusif untuk mencapai hasil. Sistem kerjanya yaitu melakukan pembimbingan melalui pengarahan sebagai bagian penugasan, memantau pelaksanaan kerja dan menilai hasil sistem kerja. Supervisor juga harus tetap mempertahankan kualitas serta kuantitas yang dihasilkan.

PT Aneka Jasa Teknik Group Gresik telah berdiri sejak tahun 2013 sebagai perusahaan bidang mechanical bergerak sebagai supplier, construction, dan maintenance plant. PT. Aneka Jasa Teknik Group Gresik telah mempunyai customer project list diantaranya adalah PT. Jaya Brix Indonesia, PT. Primergy Solution, PT. Metro Abadi Raya, PT. Indo Cement Tunggal Perkasa, PT Semen Gresik, dll. PT Aneka Jasa Teknik juga mempunyai tujuan yaitu untuk membangun kerjasama jangka panjang dengan pelanggan, dengan dukungan pelanggan, PT Aneka Jasa Teknik melakukan pemaksimalan potensi dan bisnis dengan peningkatan kualitas pelayanan, pemasaran yang kreatif, harga yang inovatif dan biaya bersaing.

PT. Aneka Jasa Teknik Gresik juga mempunyai kebijakan visi dan misi di dalam suatu perusahaan. Visi perusahaan adalah menjadikan perusahaan yang unggul; terkemuka dengan sumber daya yang handal dan profesional, sedangkan misi perusahaan yaitu dapat memberikan pelayanan One-Stop Service; memberikan 
80 I Sulismadi, Tutik Sulistyowati, Alung Vinedal

Peran Supervisor Dalam Menjaga Etos Kerja Karyawan PT Aneka Jasa Teknik Group Gresik

jaminan kualitas, harga, dan pengerjaan tepat waktu; memberi peluang kepada SDM yang berpotensi.

Secara sosiologis problem kemasyarakatan dapat digolongkan ke dalam problem sosial yang tentunya bersifat kompleks. Oleh karena itu, menjadi penting manakala dalam upaya memecahkan kemakmuran yang terdapat di karyawan dalam perusahaan juga melibatkan berbagai disiplin ilmu termasuk ilmu hubungan industrial (sosiologi). Permasalahan yang terjadi di PT. Aneka Jasa Teknik Gresik yaitu ketidaksesuaian skill karyawan dengan permintaan supervisor sehingga terjadi penurunan kinerja karyawan. Tujuan yang ingin dicapai yaitu untuk mengetahui dan menganalisis permasalahan dengan cara melakukan evaluasi terhadap peran supervisor dalam menjaga etos kerja karyawan PT. Aneka Jasa Teknik Gresik.

Pengawasan merupakan pengambilan tindakan untuk meningkatkan kinerja sehingga mendukung adanya peningkatan pada hasil. Melalui pengawasan inilah perusahaan dapat memastikan apakah kegiatan atau proses produksi telah memenuhi rencana sebelumnya. Sistem pengawasan biasanya merencanakan serta pengorganisasian. Menurut (Nielwaty et al., 2017) bahwa pengawasan merupakan sebuah hal penting agar segala aspek program dapat dijalankan sesuai rencana dan pencapaian. Kinerja SDM perusahaan sangat dipengaruhi oleh adanya fungsi pengawasan karena segala kebijakan perusahaan dapat dikendalikan oleh proses pengawasan tersebut.

Pengertian karyawan yaitu pihak yang memberikan jasanya kepada perusahaan atau organisasi yang sehingga mendapatkan upah maupun kompensasi lainnya. Menurut (Sasono \& Purwaningsih, 2015) lingkungan kerja sangatlah berpengaruh dalam kinerja karyawan. Karyawan dapat mempunyai etos kerja yang baik, dan ini menjadi komponen penting bagi keberhasilan perusahaan, apabila lingkungan kerjanya dinilai sangat mendukung atau memberikan kenyamanan baginya. Sebaliknya, jika karyawan menilai lingkungan kerjanya tidak sehat, tidak nyaman, dan tidak mendukung baginya dalam bekerja maka sangat dimungkinkan etos kerjanya lebih rendah dan keberhasilan dalam bekerja cukup sulit tercapai.

Supervisor merupakan posisi atau jabatan struktural di dalam perusahaan yang berotoritas memerintah rekan kerja yang secara struktural berada di 
dibawahnya atas arahan atau perintah atasannya. Seorang supervisor memiliki tuntutan untuk menjembatani antara manajer dan karyawan. Seperti yang telah disebutkan sebelumnya bahwa supervisor berada ditengah-tengah antara manajer dan karyawan, maka berarti tugas supervisor adalah berkomunikasi secara langsung dengan karyawan untuk mengawasi jalannya pekerjaan. Menurut (Karlina, 2009) peran supervisor adalah memusatkan perhatian untuk menemukan kesalahan atau hambatan berdasarkan standar kerja baku yang telah dirumuskan perusahaan.

Etos kerja adalah semangat kerja yang dilandasi aturan maupun norma yang berlaku di dalam perusahaan. Etos kerja juga dianggap sebagai karakteristik yang ada pada karyawan untuk menghasilkan keahlian interpersonal, inisiatif, dan dapat diandalkan. Menurut (Syafii \& Ulinuha, 2018) etos kerja yang baik adalah jika karyawan dapat melakukan pekerjaan yang telah ditentukan oleh perusahaan dengan baik, begitu pula hasilnya dapat memenuhi harapan dari perusahaan. Faktor yang mempengaruhi etos kerja yaitu faktor internal (kemampuan karyawan) dan faktor eksternal (lingkungan kerja). Sumber Daya Manusia yang berkualitas adalah nilai yang sangat tinggi atau aset bagi perusahaan. Melalui SDM yang mumpuni inilah etos kerja tinggi dapat terwujudkan.

Menanamkan etos kerja serta nilai budaya perusahaan sangat diperlukan untuk menilai suatu kinerja yang baik dalam perusahaan sehingga menjadi nilai positif yang berkontribusi dalam peningkatan kualitas SDM. Etos kerja merupakan seperangkat sikap atau pandangan mendasar yang dipegang karyawan untuk menilai bekerja sebagai suatu hal yang positif bagi peningkatan kualitas kehidupan sehingga mempengaruhi perilaku kerja dalam organisasi (Sianipar \& Salim, 2019). Etos kerja dipengaruhi oleh beberapa faktor. Menurut Donni Juni Priansa dalam (Sianipar \& Salim, 2019) etos kerja dipengaruhi oleh faktor internal (agama, pendidikan, motivasi, usia, jenis kelamin) dan faktor eksternal (budaya, sosial politik, kondisi lingkungan, struktur ekonomi, tingkat kesejahteraan, perkembangan bangsa lain). Sedangkan menurut Yousef dalam (Sianipar \& Salim, 2019) etos kerja dipengaruhi oleh beberapa hal berikut:

1. Kerja keras;

2. Komitmen dan dedikasi terhadap pekerjaan; 
82 I Sulismadi, Tutik Sulistyowati, Alung Vinedal

Peran Supervisor Dalam Menjaga Etos Kerja Karyawan PT Aneka Jasa Teknik Group Gresik

3. Kreativitas selama bekerja;

4. Kerja sama serta persaingan di tempat kerja;

5. Ketepatan waktu dalam bekerja;

6. Keadilan dan kedermawanan di tempat kerja.

Menurut (Yuliati, 2006) adapun peran supervisor untuk menjaga semangat kerja yaitu:

1. Menyampaikan rencana-rencananya terkait apa tujuannya sebagai supervisor atau dengan kata lain target-target apa yang ingin dicapai, kemudian bagaimana strategi mewujudkannya supervisor seharusnya juga dapat merancang bagaimana sistem kerja, hubungan antar posisi, dan lingkungan kerja yang baik dan nyaman bagi semua pihak. Tujuan-tujuan supervisor dalam pekerjaannya tersebut sebaiknya juga tidak mengabaikan tujuan/kepentingan dari pihak lain, baik manajemen maupun karyawan. Sehingga setiap posisi dapat mencapai tujuannya masing-masing dengan tidak saling bertentangan.

2. Membangkitkan semangat dari para anggotanya

Semangat kerja bagi karyawan sangatlah berpengaruh agar terwujudnya kualitas kinerja yang baik. Di sinilah peran supervisor sebagai bagian struktural perusahaan yang bersentuhan langsung dengan karyawan dituntut untuk dapat membangkitkan semangat kerja mereka. Semangat kerja ini biasanya akan ditimbulkan melalui proses komunikasi terkait tujuan-tujuan bersama dalam bekerja yang ingin dicapai. Fungsi ini dapat disukseskan melalui komunikasi dua arah. Proses komunikasi tersebut bertujuan untuk dapat memahami kondisi anggota kemudian menentukan bagaimana caranya dalam memberikan pengaruh.

3. Mengembangkan suasana kerjasama

Kerjasama sangatlah diperlukan karena proses produksi melibatkan komponenkomponen yang saling terkait. Apabila supervisor dapat berkomunikasi dengan karyawan secara baik, tercipta hubungan kekeluargaan, serta adanya rasa saling menghargai maka suasana kerjasama dapat lebih mudah tercapai.

4. Mengembangkan kemampuan anggota

Supervisor harus memahami kondisi masing-masing anggotanya melalui pengamatan secara langsung saat menjalankan tugasnya sebagai supervisor. Hasil 
dari pengamatan tersebut, supervisor dapat memahami kelebihan dan kekurangan masing-masing karyawan, kemudian menentukan bagaimana mengembangkan kelebihan tersebut dan bagaimana menanggulangi kekurangannya agar dapat menjadi SDM yang unggul bagi perusahaan.

\section{METODE PENELITIAN}

Penelitian ini menggunakan metode pendekatan kualitatif deskriptif. Pendekatan kualitatif digunakan untuk mendeskripsikan/memberikan penjelasan secara faktual dan lebih detil terkait kasus yang diteliti. Setting lokasi yang diambil adalah PT. Aneka Jasa Teknik Group Gresik terletak di Jalan Raya Dungus Cerme KM 3 Kabupaten Gresik, Jawa Timur. Wilayah tersebut sangat strategis karena merupakan wilayah industri, jalan bypass atau jalan alternatif jalur yang menuju Kabupaten Mojokerto dan Lamongan, dan akses jalan menuju turun tol. Prospeknya juga sangat menarik yaitu terdapat perumahan, sekolahan, pasar, puskesmas, dan perbankan.

Pengambilan data menggunakan metode observasi, wawancara, dan studi literatur untuk mendapatkan data primer dan sekunder. Wawancara merupakan sebuah aktivitas tanya jawab dengan informan yang telah ditentukan melalui hasil teknik sampling untuk menggali data suatu fenomena dari fokus penelitian. Teknik wawancara yang digunakan dalam penelitian ini yaitu wawancara terstruktur (menentukan rangkaian pertanyaan secara rinci) dan tidak terstruktur (memberikan pertanyaan secara mengalir saat proses wawancara). Observasi adalah mengamati langsung data-data yang terkait di lapangan. Data yang didapatkan melalui melihat realita yang ada tersebut akan mencatat bukti-bukti empiris pada sebuah obyek penelitian. Proses observasi memiliki kepentingan untuk memahami kondisi sekitar di lokasi penelitian, sehingga data yang didapatkan cenderung dari mana saja namun peneliti juga harus tetap berada dalam konteks penelitiannya.

\section{PEMBAHASAN}

PT. Aneka Jasa Teknik Group Gresik menggunakan sistem kerja berbasis jam sebagai aturan perusahaan. Kenyataannya, dalam pelaksanaannya perusahaan 
ini menerapkan sistem kerja harian dengan waktu kerja menyesuaikan kondisi karyawan. Waktu kerja yang diterapkan satu hari hanya 7 jam kerja. Faktor kedisiplinan tidak bergantung pada proses kerjanya saja akan tetapi waktu kerja yang sudah ditentukan perusahaan dan ditanamkan kepada karyawan itu sendiri.

Kedisiplinan itu yang ditanamkan dari perusahaan dan juga dari kesadaran diri karyawan. Hal-hal yang perlu diperhatikan terkait keterlambatan yaitu :

1. Alasan yang diberikan benar-benar logis;

2. Toleransi keterlambatan maksimal 10 menit, selebihnya tidak diperkenankan masuk kerja.

3. Tidak ada toleransi bagi "titip absen".

PT. Aneka Jasa Teknik Group Gresik menekankan kerjasama antar karyawan perusahaan. Perusahaan menganggap para karyawan sebagai partner kerja. Partner kerja harus memposisikan diri sebagai tenaga profesional supaya tercipta suasana kerja yang nyaman dan toleransi yang sesuai. Sistem harus dipatuhi dan masingmasing pihak konsisten terhadap tugas dan fungsinya masing-masing. Setiap posisi atau bagian dalam perusahaan dianggap saling membutuhkan satu sama lain, sehingga terciptalah simbiosis mutualisme.

Permasalahan yang timbul di lapangan yaitu adanya penurunan kualitas kerja karyawan menurut para supervisor. Permasalahan tersebut ditanggapi oleh supervisor dengan cara melakukan pendekatan yang lebih intensif melalui komunikasi secara langsung untuk bersama-sama menggali akar permasalahan kemudian mencari solusinya. Fungsi pengawasan melalui komunikasi secara langsung oleh supervisor kepada karyawan juga sebagai sarana untuk melakukan penilaian kepada karyawan mana yang telah siap atau layak untuk terjun di setiap proyek.

Pihak perusahaan tidak menuntut (stressing) para karyawannya atau menekankan ambisi tertentu untuk menghasilkan suatu produk. Pihak perusahaan tetap menerima masukan dari karyawan mengenai bagaimana kendala yang terjadi di lapangan, kekurangan perusahaan, kenyamanan pada sistem jam kerja, serta kondisi yang diharapkan para karyawan. Seperti halnya perencanaan perusahaan terhadap suatu produk tidak sesuai dengan kondisi para karyawan di lapangan 
artinya pihak perusahaan harus mendengarkan secara langsung kesulitan yang dialami oleh para karyawan.

Kegiatan di perusahaan PT. Aneka Jasa Teknik Group Gresik terbagi menjadi 2 shift. Shift pertama dilakukan pada pukul 08.00-16.00 WIB, untuk shift kedua dilakukan pada pukul 16.00-21.00 WIB. Dengan adanya 2 shift, pengerjaan produk yang disepakati dengan konsumen dapat tepat waktu dengan tidak mengabaikan hak-hak karyawan. Sistem kerja lembur di perusahaan PT. Aneka Jasa Teknik Group Gresik berpengaruh pada peralatan yang digunakan. Artinya, peralatan yang digunakan di perusahaan tersebut memiliki masa pemakaian yang terbatas sehingga perusahaan perlu adanya penambahan peralatan untuk menyelesaikan suatu produk. Adanya sistem kerja lembur memiliki dampak positif dan negatif. Dampak positif untuk karyawan yaitu memotivasi para karyawan untuk memaksimalkan hasil dan berpengaruh pada upah. Dampak negatifnya adalah para karyawan mengalami kejenuhan dan berdampak pada psikologis ketika bekerja sehingga berpengaruh pada kinerja karyawan yang tidak maksimal.

Fungsi dari supervisor tidak hanya memperhatikan karyawan saja, akan tetapi juga memperhatikan pelaksana (mandor). Supervisor berfungsi menjadi jembatan untuk ke manajemen. Supervisor juga berfungsi sebagai pendengar aspirasi para karyawannya. Supervisor memiliki tanggung jawab sebagai fungsi pengawasan atas kinerja karyawan dalam mengeksekusi rencana dari manajer. Tanggung jawab supervisor pada organisasi perusahaan yaitu sebagai pengontrol atau pengawas para karyawan secara langsung. Supervisor harus mengupayakan diri agar dapat mengatasi masalah yang terjadi di lapangan sebisa mungkin tanpa melibatkan pimpinan perusahaan terlebih dahulu.

Penghargaan karyawan diberikan melalui penambahan upah kerja (ceperan), hal ini supaya membuat karyawan lebih semangat untuk bekerja. Di semua bidang pekerjaan hal ini sering terjadi karena untuk menghargai jerih payah seseorang yang bekerja keras. Hal tersebut juga terdapat konsekuensinya, karena ada catatan khusus kinerja bagi karyawan lain sehingga terlihat antara yang benar-benar bekerja keras maupun yang tidak. Sistem yang ada di perusahaan itu membuat karyawan bisa introspeksi diri untuk hal yang penting dan tidaknya dalam pekerjaan. Namun 
86 I Sulismadi, Tutik Sulistyowati, Alung Vinedal

Peran Supervisor Dalam Menjaga Etos Kerja Karyawan PT Aneka Jasa Teknik Group Gresik

demikian, penilaian karyawan tidak hanya dilihat dari sisi supervisor saja pada saat pengawasan tetapi juga dilihat dari pendapat karyawan lain yang berada di bidang tersebut.

Seorang supervisor melihat karyawan tidak hanya melalui pekerjaan tetapi juga memperhatikan aspek psikologis karyawan tersebut, karena ada karakteristik karyawan yang baik dalam kemampuan berfikirnya tetapi dalam penerapan lapangan atau praktek masih kurang atau Penilaian supervisor juga melihat karyawan mempunyai karakter masing-masing untuk melakukan pekerjaan yang harus dikerjakan sehingga supervisor dapat memilih siapa yang akan mengerjakan proyek tertentu.

Penerapan menjaga etos kerja oleh PT. Aneka Jasa Teknik Group Gresik untuk mendisiplinkan karyawan belum sepenuhnya maksimal dikarenakan tidak semua karyawan memiliki keahlian yang sama. Sehingga supervisor dapat meningkatkan etos kerja pengawasan untuk karyawan yang memiliki skill-nya masing-masing. Karyawan tidak dituntut oleh pihak perusahaan diluar batas kemampuan, karena jika karyawan dituntut maka pekerjaan mereka tidak begitu maksimal. Pekerjaan supervisor tidak hanya melihat atau mengawasi karyawan yang sedang bekerja tetapi supervisor juga memperhatikan karakter dan skill karyawan. Analisa pengawasan supervisor dalam etos kerja karyawan oleh penulis bersama supervisor PT. Aneka Jasa Teknik Group Gresik ini adalah sebuah tool untuk mengelola indikator dan penilaian stakeholder yang membutuhkannya.

\section{KESIMPULAN}

Supervisor adalah jabatan dalam struktur perusahaan yang memiliki kuasa dan otoritas untuk mengeluarkan perintah kepada rekan kerja bawahannya di bawah arahan jabatan atasannya. Seorang supervisor dituntut mampu bertindak sebagai jembatan antara manajer dan staf pelaksana atau staf bawah. Tugas seorang supervisor diharuskan untuk berhubungan secara langsung dengan stafnya, hal ini untuk menentukan kelancaran selesai tidaknya sebuah proyek. Supervisor harus melakukan pendekatan secara langsung dengan karyawan yang bertujuan 
untuk menemukan permasalahan yang ada dalam menurunnya kinerja karyawan yang menyebabkan penurunan kualitas produk.

PT Aneka Jasa Teknik Group menekankan kerja sama antar bagian perusahaan, tetapi setiap orang juga harus bertanggung jawab atas posisinya masingmasing. Sanksi tegas juga diberlakukan jika ada pelanggaran-pelanggaran yang tidak dapat ditolerir, walaupun perusahaan tidak menuntut karyawan secara berlebih. Jika ada permasalahan terhadap karyawan maka supervisor harus turun tangan. Supervisor harus mampu memecahkam masalah yang terjadi pada karyawan di lapangan serta memberikan motivasi-motivasi agar setiap karyawan memiliki etos kerja yang baik.

\section{DAFTAR PUSTAKA}

Dadang, \& Heriyanto, F. 2020. Pengaruh Briefing Kerja Dan Peran Supervisor Terhadap Kinerja Karyawan Pada PT.Gmf Aeroasia Tbk. Dynamic Management Journal, 4(1), 53-60. https://doi.org/10.31000/dmj.v4i1.2490

Nielwaty, E., Prihati, \& Zuhdi, S. 2017. Pengaruh Pengawasan Terhadap Kinerja Pegawai Disperindag Sub Bidang Pengawasan Barang Dan Jasa Provinsi Riau. Jurnal Niara, 10(1), 1-5. https://doi.org/10.31849/nia.v10i1.1882

Sasono, E., \& Purwaningsih, D. 2015. Analisis Pengaruh Suasana Lingkungan Kerja Terhadap Kinerja Para Guru dan Pegawai Pada SMP Negeri 6, Kecamatan Batang, KAbupaten BAtang. Jurnal STIE Semarang, 30(3), 175-182. http://jurnal3.stiesemarang.ac.id/index.php/jurnal/article/view/130

Sianipar, R., \& Salim, V. 2019. Faktor Etos Kerja Dan Lingkungan Kerja Dalam Membentuk "Loyalitas Kerja" Pegawai Pada Pt Timur Raya Alam Damai. Jurnal Ilmiah Akuntansi Dan Manajemen, 15(1), 15-27. https://jurnal.ubharajaya.ac.id/index.php/jiam/article/view/539

Syafii, M., \& Ulinuha, M. 2018. Pengaruh Etos Kerja Dan Budaya Organisasi Terhadap Kinerja PT. Ananda Jataka Bayu Sejahtera (AJBS) Dikota Gresik. Jurnal Fakultas Ekonomi, 07(01), 61-69. http://journal.aakdelimahusadagresik.ac.id/index.php/GemaEkonomi/article/vie $\mathrm{w} / 732$

Titisari, M. M. W., \& Haryono, A. T. 2016. Analisis pengaruh karakteristik organisasi, etos kerja dan disiplin kerja terhadap performa perusahaan dengan efektifitas kinerja karyawan sebagai variabel intervening. Journal of Management, $2(2)$, $1-47$. 
88 I Sulismadi, Tutik Sulistyowati, Alung Vinedal

Peran Supervisor Dalam Menjaga Etos Kerja Karyawan PT Aneka Jasa Teknik Group Gresik

https://jurnal.unpand.ac.id/index.php/MS/article/view/566

Yuliati, F. 2006. Peran supervisor dalam meningkatkan produktivitas kerja karyawan bagian produksi di pt sari warna asli III karanganyar tahun 2006. Skripsi: Universitas Negeri Surakarta, 1-89. https://digilib.uns.ac.id/dokumen/detail/5477/Peran-supervisor-dalammeningkatkan-produktivitas-kerja-karyawan-bagian-produksi-di-PT-SariWarna-Asli-III-Karanganyar-tahun-2006 